UDC: $316.485 .6: 321.7(497.7) " 2001 "$

341.171(497.7:4-672EУ)

327.51(497.7:100-622HATO)

DOI: $10.46763 /$ SCGW212371g

Original research paper

\title{
OHRID FRAMEWORK AGREEMENT AND \\ EURO-ATLANTIC INTEGRATION 20 YEARS LATER
}

\author{
Jordanka Galeva \\ Assistant professor, PhD, Faculty of law, Faculty of Law, \\ University Goce Delchev-Shtip \\ e-mail: jordanka.galeva@ugd.edu.mk
}

\begin{abstract}
Macedonia became an independent state in 1991 and since its independence has declared its Euro-Atlantic membership aspiration, adapting to the criteria and conditions that emerged from this process. Ten years after its independence, an armed conflict erupted in 2001, which ended with signing of the Ohrid Framework Agreement, which also became one of the basic conditions and criteria for measuring the country's progress in Euro-Atlantic integration. In 2005, the country received the status of a candidate for EU integration, in 2008 it was ready to join NATO, but due to the name dispute with Greece, that happened only after the signing of the Prespa Agreement. On March 27, 2020, Macedonia became a member of NATO, and the day before the European Council approved the decision of the Council to open accession negotiations. The purpose of this paper is to see how the OFA's principles have contributed to the country's progress in the Euro-Atlantic process.
\end{abstract}

Keywords: Ohrid Framework Agreement, Republic of North Macedonia, multiculturalism, Euro-Atlantic integration, minority rights

\section{ОХРИДСКИ РАМКОВЕН ДОГОВОР И ЕВРО-АТЛАНТСКАТА ИНТЕГРАЦИЈА 20 ГОДИНИ ПОДОЦНА}

\author{
Јорданка Галева \\ Доц., Д-р., Правен Факултет, Универзитет Гоце Делчев - Штип \\ e-mail: jordanka.galeva@ugd.edu.mk
}

\section{Апстракт}

Македонија стана независна држава во 1991 година и уште од самото осамостојување се изјасни за евро-атлантската интеграција, прилагодувајќи се на критериумите и условите кои произлегоа од овој процес. По десет години од нејзиното осамостојување, во 2001 година избувна вооружен конфликт кој се заврши со потпишување на Охридскиот Рамковен Договор, кој исто така стана еден од основните услови и критериуми за мерење на напредокот на земјата во евро-атлантската интеграција. Во 2005 година земјата доби статус на кандидат за интеграција во ЕУ, во 
2008 година беше подготвена да влезе во НАТО, но заради спорот со името со Грција, истото се случи само по потпишувањето на Преспанскиот договор ${ }^{1}$. На 27 март 2020 година Македонија стана членка на НАТО, а ден претходно Европскиот совет ја одобри одлуката на Советот за отворање на преговорите за пристапување. Целта на овој труд е да се види колку принципите врз кои се заснова ОРД придонесоа за напредокот на земјата во евро-атлантскиот процес.

Клучни зборови: Охридски рамковен договор, Република Северна Македонија, мултикултурализам, евро-атлантска интеграција, малцински права

\section{Вовед}

Во 2001 година се одбележаа десет години од независноста на Македонија, a истата година се потпиша Спогодбата за Стабилизација и Асоцијација 2 (Спогодбата) со ЕУ и Охридскиот Рамковен Договор 3 (ОРД) кој стави крај на вооружениот конфликт. Од една страна, Македонија беше прва потписничка на Спогодбата од Западен Балкан, а последна која беше зафатена од вооружен конфликт. Потпишувањето на Охридскиот рамковен договор се случи како резултат на добрата волја на инволвираните страни и на вклученоста на меѓународната заедница за изнаоѓање на мирно решение и избегнување на понатамошно разгорување на конфликтот. „Еланот, кој се чувствуваше во договорот беше надежта за стабилизација, мир и интеграција во Европската Унија и НАТО. Имено ОРД освен што требаше да одговори на внатрешните потреби, вооедно претставуваше политика плус која ќе довде до остварување на условите поставени од Меѓународната Заедница, во рамките на Спогодбата и последователните политики за евроинтеграција. Во анализата на трудот водечкото прашања е: дали принципите на ОРД и нивното имплементирање доведоа до напреднување на Македонија во евро-аталнтската интеграција? За да се одговори на ова прашање направена е анализа на имплементацијата на основните принципи и точки на ОРД и нивната поврзаност со евро-атлантскиот процес.

\footnotetext{
${ }^{1}$ Спогодба, Конечна Спогодба за решавање на разликите опишани во резолуииите 817 (1993) и 845 (1993) на Советото за безбедност на Обеддинетите Нации, за престанување на важноста на привремената спогодба од 1995 г. и за воспоставување на стратешко партнерство меѓу страните (12.06.2018), Влада на РМ, (02.05.2021) Retrieved from https://vlada.mk/node/17422

2 Stabilization and Association Agreement, (26.03.2001) Council of The European Union, Brussels, (05.05.2021) Retrieved from http://ec.europa.eu/enlargement/pdf/the former_yugoslav republic of macedonia/saa03 01 en.pdf

3 Framework Agreement, (13.08.2001), Organization for Security and Co-operation in Europe, (02.05.2021) Retrieved from https://www.osce.org/files/f/documents/2/8/100622.pdf
} 


\section{1. ПринципитенаОхридскиотРамковен Договоринивнаимплементација}

Охридскиот Рамковен Договор се состои од десет точки, анекс А, во кои се содржани уставните амандмани, анекс Б, во кои се наведени законските измени и анекс Ц, насловен имплементација и градење на доверба. Во продолжение се наведени првите седум точки, од кои произлегоа бројни уставни и законски измени, додека точките 8,9 и 10 ги содржат одредбите за имплементација, анексите и завршните одредби.

Во првата точка на Договорот се содржани основните принципи врз кои се заснова самиот договор и се однесуваат на: отфрлање на употреба на насилство за остварување на политички цели (прв принцип); зачувување на суверенитетот и територијалниот интегритет на Македонија и нејзиниот унитарен карактер (втор принцип); одразување на мултиетничкиот карактер во јавниот живот (трет принцип); исполнување на потребите на граѓаните преку уставот, согласно развојот и созревањето на демократската држава (четврт принцип); развој на локалната самоуправа (со цел поттикнување на учеството на граѓаните во демократскиот живот и унапредување на почитувањето на идентитетот на заедниците (петти принцип). Врз основа на овие принципи се уредени другите точки во ОРД и истите се однесуваат на: прекин на непријателствата преку разоружување на етничките албански вооружени групи, и нивно целосно доброволно распуштање (точка 2); развој на децентрализрана власт преку ревизијата на општинските граници и избор на локалните началници на полицијата преку советите на општините од листи на кандидати предложени од страна на Министерството за внатрешни работи (точка 3); недискриминација и правична застапеност која ќе се спроведува пред се преку вработувањата во јавната администрација и јавните претпријатија, со посебен осврт на вработување во полициските служби (точка 4); посебни собраниски процедури, кои подразбираат примена на двојно мнозинство при гласањето, односно мнозинство на гласови во рамките на што ќе мора да има мнозинство на гласови на пратениците кои тврдат дека припаѓаат на заедниците кои не се мнозинско население во Македонија (точка 5); образование и настава на мајчиниот јазик и унифицирани стандарди за академските програми во основното и средното образование, финансирање од страна на државата на високо образование на јазиците на кои што зборуваат најмалку 20 проценти од населението во Македонија; одредување на условите и начинот на службена употреба на јазиците, кои се различни од македонскиот јазик, а го зборува $20 \%$ од населението (точка 6); и, изразување на етничкиот идентитет преку јавна употреба на сопствени симболи (точка 7).

Првиот принцип содржан во ОРД, предвидува иелосно и безусловно отфрлање на употреба на насилство за остварување на политички цели и се 
поврзува со точка 2 од самиот договор, насловена прекин на непријателствата. Во овој дел Договорот предвидуваше целосно доброволно разоружување на етничките албански вооружени групи и прекин на огнот. Разоружувањето кое го спроведуваше НАТО во рамките на мисијата Неопходна жетва траеше еден месец, а потоа се продолжи со мисијата Килибарна Лисища, која имаше мандат да ги штити набљудувачите на ОБСЕ и НMЕУ кои пак беа ангажирани за обезбедување на спроведување на ОРД во поранешните кризни региони. Преку Мисијата Неопходна жетва се собраа вкупно 3.875 парчиња оружје, односно 375 повеќе од договореното, од кои 161 помошни орудија (на пр. минофрлачи) и 483 пушкомитралези и беа предадени речиси 400.000 парчиња муниција, гранати и мини ${ }^{4}$. Последователно со завршување на оваа мисија, се случија уште неколку немили настани кои имаа на некој начин етничка позадина и претставуваа обид за дестабилизација на државата, а се однесуваат на убиството кај Смилковско езеро (случај Монструм) од 12 април 2012 година, настаните во Диво Насеље од 9 мај 2015 година и упадот во Собранието на РМ на 27 април 2017 година Во сите три случаи поголемиот број од обвинетите се обвинети за тероризам, а мотивите за настаните се следните: во однос на случајот Монструм, тогашната министерка за внатрешни работи Јанкуловска изјавила дека мотивот е да се предизвика верски и меѓунационални тензии, додека обвинителката Фетаи при последната пресуда од 2021 година, изјави дека се работи за терористички акт кој претставува обид за предизвикување на меѓуетнички конфликт и

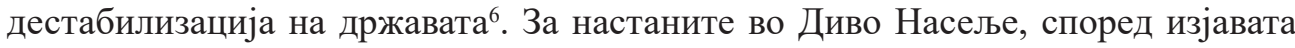
на тогашниот премиер на државата, Никола Груевски, мотивот на оваа група била дестабилизација на Македонија구 додека пет години подоцна, во јуни 2020 година, директорот на Агенцијата за разузнавање Еролд Муслиу, изјави дека

\footnotetext{
${ }^{4}$ Laity, M., (2009), Preventing war in Macedonia, Pre - Emptive Diplomacy for the 21 st Century, RUSI Кралски институт на заедничките служби, (стр.84); (превод: Марк Лејти, Спречување војна во Македонија Превентивна дипломатија за 21 век, Вајтхол труд, Фндација Институт отворено Општество-Македонија, 2009) (02.05.2021) Retrieved from https://www.fosm.mk/CMS/Files/ Documents/Sprecuvanje-vojna-vnatresni-mark-lejti.pdf

${ }_{5}^{5}$ Во убиството кај Смилковско езеро кое се случи на велигденскиот Велики четврток се убиени 4 момчиња помлади од 21 година и едно повозрасно лице, сите етнички македонци. За убиството се обвинети пет лица етнички албанци, од кои три лица (двајца во бегство) се осудени за тероризам со казна доживотен затвор, додека други двајца само на отслужување на затвор. Во престрелките во Диво Насеље, операција која беше организирана за да да ја разбие наоружената група, да го заплени оружјето и да спречи терористички напад загинаа 8 припадници на полициските служби и водачите на терористичката група. Преживеаните 33 лица од вооружената група, етнички албанци од Македонија и Косово во ноември 2017 година беа осудени за тероризам и терористичка организација.

${ }^{6}$ Марушиќ, J., С., (22.02.2021) Случајот Монструм пред својата завршница, Balkan Transitional justice, https://balkaninsight.com/ (19.06.2021) Retrieved from https://www.washingtonpost.com/news/ monkey-cage/wp/2017/05/29/this-is-why-the-west-should-pay-attention-to-the-drama-in-macedonia

${ }^{7}$ Арифи, Б., (09.05.2018), Диво Насеље: Македонска шпионска мистерија, Призма.мк, Скопје, (19.06.2021) Retrieved from https://prizma.mk/divo-nasele-makedonska-shpionska-misterija/
} 
имаат нови докази и дека за нападот преовладувал политичкиот мотив иако се споменува и финансискиот момент ${ }^{8}$. Во однос на упадот во Собранието, за кое пишуваше дури и Вашингтон Пост ${ }^{9}$, мотивот беше изборот на новиот претседател на Собранието ${ }^{10}$, од редовите на албанската партија ДУИ, а според одредени обвинети ${ }^{11}$ позадината била Тиранската платформа ${ }^{12}$.

Во однос на вториот принцип кој се однесува на зачувување на суверенитетот и територијалниот интегритет на Македонија и нејзиниот унитарен карактер и петтиот принцип кој се однесува на развој на локалната самоуправа истите се тесно поврзани, односно подржани со реализација на точка 3 од самиот договор, кој предвидува развој на децентрализрана власт ${ }^{13}$. За отпочнување на овој процес, најнапред се спроведе попис на населението и домаќинствата, а потоа се донесоа и низа закони, меѓу кои Закон за локална самоуправа, Закон за финансирање на единиците на локланата самоуправа,

\footnotetext{
${ }^{8}$ Стојначов, С., (26.06.2020), Агенција за разузнавање има нови сознанија за „Диво насеље,, Радио Слободна Европа, (02.05.2021) Retrieved from https://www.slobodnaevropa.mk/

${ }^{9}$ Sokhey W. S., Gjukovikj, D, (29.05.2017) This is why the West should pay attention to the drama in Macedonia, Washington Post, (19.06.2021) Retrieved from https://www.washingtonpost.com/news/ monkey-cage/wp/2017/05/29/this-is-why-the-west-should-pay-attention-to-the-drama-in-macedonia

10 Ландов, К., Русковска за 27 април: Се се знаело, било испланирано, не се знаел датумоттоа го докажавме (01.07.2021), Alon.mk, (01.07.2021) Retrieved from https://a1on.mk/macedonia/ ruskovska-za-27-april-se-se-znaelo-bilo-isplanirano-ne-se-znael-datumot-toa-go-dokazhavme/
}

${ }^{11}$ Кољо: Политичарите не изманипулираа со „тиранската платформа,, (21.02.2019), Tocka.com.mk (19.06.2021) Retrieved from https://tocka.com.mk/vesti/298779/koljo-politicarite-n-izmanipuliraa-sotiranskata-platforma

12 Маролов, Д., Стојановски, С., (2017) Охридскиот рамковен договор наспроти Тирана платформа, Општествените промени во глобалниот свет, Зборник на трудови „Општествени промени во глобалниот свет,, , Универзитет Гоце Делчев, Штип (865-885)

${ }^{13}$ Со амандман XVI се заменува ставот 5 на членот 114 од Уставот на Република Македонија кој сега гласи: Локалната самоуправа се уредува со закон кој се донесува со двотретинско мнозинство гласови од вкупниот број пратеници, при што мора да има мнозинство гласови од вкупниот број пратеници кои припаѓаат на заедниците кои не се мнозинство во Република Македонија. Законите за локално финансирање, локални избори, општинските граници и за градот Скопје, се донесуваат со мнозинство гласови од присутните пратеници, при што мора да има мнозинство гласови од присутните пратеници кои припаѓаат на заедниците кои не се мнозинство во Република Македонија. Со точката 1 на амандманот XVII се заменува ставот 1 на членот 115 од Уставот на Република Македонија, а со точката 2 се заменува ставот 2 на членот 117 од Уставот на Република Македонија и новите членови гласат: Во единиците на локалната самоуправа граѓаните непосредно и преку претставници учествуваат во одлучувањето за прашања од локално значење, а особено во областите на јавните служби, урбанизмот и руралното планирање, заштитата на околината, локалниот економски развој, локалното финансирање, комуналните дејности, културата, спортот, социјалната и детската заштита, образованието, здравствената заштита и во други области утврдени со закон. Во градот Скопје граѓаните непосредно и преку претставници учествуваат во одлучувањето за прашања од значење за градот Скопје, а особено во областите на јавните служби, урбанизмот и руралното планирање, заштитата на околината, локалниот економски развој, локалното финансирање, комуналните дејности, културата, спортот, социјалната и детската заштита, образованието, здравствената заштита и во други области утврдени со закон. 
Закон за територијална организација на локалната самоуправа и други. Согласно Законот за територијална организација на локалната самоуправа, во 2004 година се креираа 84 општини и Градот Скопје, од кои 32 општини со високо ниво на мултикултурален состав на населението. Според ваквата поделба, во 19 општини припадниците на немнозинските заедници, преставуваа мнозинството од населението, и тоа албанците во 16 општини, турците во 2 општини и ромите во една општина. Со општинските измени од 2013 година пак, во општината Кичево беа инкорпорирани 4 општини, намалувајќи го на тој начин вкупниот број на општини од 84 на 80.

Новата општинска поделба не само што овозможи реализација на процесот на децентрализација, туку претставуваше и основа за имплементирање на третиот принцип со кој се предвидува одразување намултиетничкиот карактер во јавниот живот. Реализацијата на овој принцип е тесно поврзана со точките 6 и 7 од ОРД кои предвидуваа воведување на употреба на друг службен јазик различен од македонскиот јазик и кирилското писмо и употреба на симболи преку кои ќe се истакнува идентитетот на немнозинските заедници. Овие точки се имплементираа преку уставни и законски измени, а додатно на нив се измени и законот за празници и се отпочна со балансирање на застапеноста на припадниците на етничките заедници во јавните и државни служби.

Како јавната сфера доби мултиетнички карактер?

Во2008година беа донесени Законот заупотреба најазицитекои гозборуваат најмалку $20 \%$ од граѓаните во РМ и во единиците на локалната самоуправа и Закон за заштита и унапредување на правата на припадниците на заедниците кои се помалку од $20 \%$ во $\mathrm{PM}^{14}$. Врз основа на овие закони и општинските измени од 2013 година кога во општината Кичево беа инкорпорирани 4 општини, во 27 општини покрај македонскиот јазик, како службен јазик се употребува албанскиот јазик, во 3 општини турскиот јазик, а српскиот и ромскиот јазик во една општина. Врз основа пак на одлука на комисиите во општините, турскиот е воведен како службен јазик во дополнителни 5 општини, а српскиот, ромскиот, влашкиот и бошњачкиот се воведени уште во една општина секој ${ }^{15}$. Оттука сумарано во 22 општини покрај македонскиот јазик се употребува јазик од уште од една немнозинска заедница, во 7 се употребуваат јазици уште од две немнозински заедници, а во 2 општини се употребуваат дури три јазици од немнозинските заедници. Во 8 општини пак како службени се воведени и

\footnotetext{
${ }^{14}$ Закон за употреба на јазиците кои го зборуваат најмалку $20 \%$ од граѓаните во РМ и во единиците на локалната самоуправа, (13 август 2008), Службен Весник, бр. 101 год. LXIV, Скопје; Закон за заштита и унапредување а правата на припадниците на заедниците кои се помалку од $20 \%$ во РМ, (22 јули 2008), Службен Весник бр. 92 год. LXIV, Скопје

${ }^{15}$ Службената употреба на другите јазици кои се различни од македонскиот предвидуваа нивна употреба во советите, во комуникација на граѓаните со органите и телата, јавните претпријатија, при публикување на службени гласници, јавни известувања, пишување на табли на општински згради, патни знаци, имиња на улици и инфраструктурни објекти.
} 
јазиците на немнозинските заедници кои се помалку од $20 \%$ од населението во тие општини ${ }^{16}$. Областите и сферите во кои се употребува друг службен јазик беа дополнети и проширени со последниот Закон за употреба на јазиците од 2018 година ${ }^{17}$ кој беше донесен без гласање од страна на опозицијата и без потпис на тогашниот Претседател на Републиката, Горѓе Иванов. Во член 1 од овој закон се одредува дека на целата територија на РМ и во нејзините меѓуународни односи, службен јазик е македонскиот јазик и неговото кирилско писмо. Друг јазик што го зборуваат најмалку 20\% од граѓаните (албански јазик), истот така, е службен јазик и неговото писмо, согласно законот ${ }^{18}$. Во однос на употребата на локалната самоуправа се одредува дека во единиците на локалната самоуправа јазикот и писмото што го користат најмалку $20 \%$ од граѓаните е службен јазик, покрај македонскиот јазик и неговото кирилско писмо, додека за употребата на јазиците и писмата на кои зборуваат помалку од $20 \%$ од граѓаните во единиците на локалната самоуправа, одлучуваат органите на единиците на локалната самоуправа. Освен што се проширени сферите ${ }^{19}$ на употреба на јазикот кој е зборуван од најмалку 20\% од населението, со чл. 8 се воведува дека книжните и ковани пари, како и поштенските марки ќе содржат симболи што го претставуваат културното наследство на граѓаните што го зборуваат македонскиот јазик и јазикот што го зборуваат најмалку $20 \%$ од граѓаните, а нивниот јазик се пренесува и на поштенските марки, уплатници, фискални извештаи издадени од институциите кои се наведени во чл.1 како и на бандеролите, на униформите на полицијата, пожарникарството, здравството, во Скопје и во општините во кои најмалку 20\% од граѓаните зборуваат службен јазик различен од македонскиот. За имплементација на овој закон се донесе и Закон за инспекторат за употреба на јазиците и се отвори Агенција за примена

\footnotetext{
16 Близнаковски, Ј., (Април 2014), Локални јазични политики за немнозинските заедници, можности за поефективна имплементаиија, Институт за демократија Социетас ЦивилисСкопје, Институт за развој на заедницата, (стр.23-24), (02.05.2021) Retrieved from https://idscs.org. $\mathrm{mk} / \mathrm{wp}$-content/uploads/2009/08/ljp-nemnozinski-zaednici-mkd.pdf

${ }^{17}$ Указ за прогласување на Закон за употреба на јазиците, (14.03.2018), Агенција за примена на јазикот, (02.05.2021) Retrieved from https://apj.gov.mk/wp-content/uploads/2019/06/Zakon-zaupotreba-jazitsite-14-01-2019.pdf

$\frac{18}{18}$ Покрај македонскиот јазик, јазикот што го зборуваат 20\% од граѓаните на Република Македонија и неговото писмо, има службена употреба во сите органи на државната власт во Република Македонија, централни институции, јавни претпријатија, агенции, дирекции, установи и организации, комисии, правни лица кои вршат јавни овластувања согласно закон и други институции, службен јазик покрај македонскиот јазик и неговото писмо е на начин определен со овој закон.

19 Во постапка пред нотар, во матична евиденција, во одредени образци (чл.10, чл.12, чл.13); на гранични премини на РМ и аеродромите (каде се наоѓаат подрачја во кое најмалку $20 \%$ од граѓаните зборуваат јазик различен од македонскиот), како и за имиња на улица, плоштад, мост и други инфраструктурен објект во сите единици на локалната самоуправа каде што најмалку $20 \%$ од граѓаните зборуваат јазик различен од македонскиот јазик, како и во Скопје (се пишува на македонски јазик и неговото кирилско писмо како и на јазикот што го зборуваат најмалку $20 \%$ од граѓаните и неговото писмо како и на јазиците што се општоприфатени од меѓународната заедница (чл.16).
} 
на јазикот во РМ.

Во однос на употреба на симболите на немнозинските заедници во 2005 година се донесе Закон за употреба на знамињата на заедниците во PM, а во 2011 година Закон за изменување и дополнување на Законот за употреба на знамињата на заедниците во $\mathrm{PM}^{20}$. Според член 4 од овој закон во единиците на локалната самоуправа во кои граѓани припадници на заедницата се повеќе од 50\% од населението во таа единица на локалната самоуправа, пред и во објектите на органите на единицата на локалната самоуправа пред и во објектите на органите на единицата на локалната самоуправа, постојано се истакнати знамето на Република Македонија и знамето на таа заедница. Покрај ова се направи и измена на Законот за празниците на Република Македонија ${ }^{21}$, со кој се воведуваат и нови празници, категоризирани како „државни празници на Република Македонија“ и „празници на Република Македонија“ (Православните Божиќ и Велигден и исламскиот Рамазан Бајрам). Потоа се слават неколку празници на верските заедници во Македонија (Бадник, Водици, Велики Петок, Духовден, Голема Богородица за православните христијани; Курбан Бајрам за муслиманите; првиот ден на Божик, вториот ден на Велигден и Празникот на сите светци за католиците; и Првиот ден на Јом Кипур за припадниците на еврејската заедница) и празниците на секоја уставно признаена немнозинска заедница ${ }^{22}$.

Во однос на точката 4 насловена соодветната и правична застапеност на сите граѓани кои припаѓaат на сите заедници во органите на државната власт и другите јавни иснтитуцчии на сите нивоа, иако можеби оваа одредба директно не се однесува на реализација на третиот принцип, истата во ова истражување ќе биде поврзана со истиот, земајќки во предвид дека предвидува спроведување на недискриминација и правична застапеност во јавната администрација и јавните претпријатија, што значи во јавната сфера. Оваа одредба најпрвин беше вметната во уставните темелни вредности (со амандманот 6 се дополни членот 8 во алинеја 2), врз чија основа се изменија низа закони, а во февруари 2003

\footnotetext{
20 Членот 5 одредува во кои околности се истакнува знамето на заедниците пред и во објектите на државните органи, јавните служби и правните лица основани од државата, јавните служби и правните лица основани од единицата на локалната самоуправа, на улиците, плоштадите и други инфраструктурни објекти.

Закон за употреба на знамињата на заедницте во РМ, (19.07.2005), Службен весник на РМ, бр.58/05 и Закон за изменување и дополнување на закон за употреба на знамињата на заедницте во РМ, (25.07.2011), Службен весник на РМ бр.100 од 2011

21 Закон за изменување на Законот за празниците на Република Македонија, (15.02.2007), Службен весник на РМ бр. 18 од 2007

22 Денот на албанската азбука - за припадниците на албанската заедница, Денот на настава на турски јазик - за припадниците на турската заедница, Свети Сава - за припадниците на српската заедница, Меѓународниот ден на Ромите - за припадниците на ромската заедница, Националниот ден на Власите - за припадниците на влашката заедница и Меѓународниот ден на Бошњаците - за припадниците на бошњачката заедница.
} 
година Владата на Република Маледонија ги усвои Основите за подготовка на програмата за подобрување на соодвтната и правична застапеност на заедниците во јавната администрација и јавните претпријатија. Овие мерки предвидуваа јакнење на способностите за превод, отворање на двојазични места, анализа на слободни места за вработување во администрацијата и вработување во секторот за односи помеѓу граѓаните и јавната администрација. Во периодот кој ќе следи ќе се спроведува „забрзано вработување,, на припадници на немнозинските заедници со цел да се достигне баланс помеѓу процентуалноста на населението по етничка припадност и нивна застапеност во државните и јавните институции. Првите вработувања беа реализирани во полициските служби каде до јули 2002 година беа вработени 500 лица, а до следниот јули 2002 уште нови 500 од припадниците на заедниците кои не се мнозинско население. Во 2003 година се донесе документот Основи за подготовка на програмата за подобрување на соодветната и правична застапеност на заедниците во јавната администрација и јавните претпријатија во чии рамки се отвараа нови работни двојазични места ${ }^{23}$, а во 2007 година беше донесена Стратегија за соодветна и правична застапеност на припадниците на сите заедници кои не се мнозинство во Македонија, согласно која се отпочна со планирано вработување. Најголем број вработувања од редовите на припадниците од немнозинските заедници беа реализирани во Секретеријатот за спроведување на Рамковниот договор кој функционираше до 2019 година, а еден од клучните проблеми кои настанаа при негово затварање беше, каде да се префрлат вработените.

Во однос на четвртиот принцип, кој се однесува на исполнување на потребите на граѓаните преку уставот, согласно развојот и созревеањето на демократската држава, неговото остварување е најтесно поврзано со имплементација на амандманите кои произлегоа од ОРД ${ }^{24}$ и со примената на

\footnotetext{
${ }^{23}$ При првичната направена анализа беше забележан пораст на бројот на немнозинските заедници во јавната администрација (пред се на албанската заедница, благо зголемување на бројот на службеници од редовите на другите немнозински заедници со исклучок на србите и оние кои припаѓаат во категоријата други), во одредени институции (Народниот правобранител, Затворите, Јавното обвинителство) и во министерства (Министерство за образование и наука, Министерство за економија и Министерство за здравство). Галева, Ј., (2016), Влијанието на Охрдискиот рамковен договор врз правната регултива и пракса за вработување, 349.2:340.13]:321.7(497.7),2001“, Списание на научни трудови „Меѓународен дијалог Исток-Запад,, Vol.3, N.2, Меѓународен центар за славјанска просвета- Свети Николе, Свети Николе, (стр.197-202).

${ }^{24}$ Со точката 1 на Амандман IV се заменува Преамбулата од Уставот на Република Македонија од 1991; со Амандман V се заменува членот 7 од Уставот на Република Македонија; со точката 1 на Амандман VI се дополнува алинејата 2 на членот 8 од Уставот на Република Македонија; со точката 1 на Амандман VII се заменува ставот 3 на членот 19, а со точката 2 се заменува ставот 4 на членот 19 од Уставот на Република Македонија; со Амандман VIII се заменува членот 48 од Уставот на Република Македонија; со точката 1 на Амандман IX се заменува ставот 2 на членот 56 од Уставот на Република Македонија; со Амандман X се заменува членот 69 од Уставот на Република Македонија; Со точката 1 на Амандман XI се заменува ставот 1 на членот 77, а со точката 2 се дополнува ставот 2 на членот 77 од Уставот на Република Македонија; со точката
} 
таканереченото Бадинтерово правило ${ }^{25}$. Согласно Амандман XVIII се додаде нов став 4 на член 131 од Уставот на Република Македонија и истиот предвидува дека одлука за измена на Преамбулата, членовите за локална самоуправа, членот 131, која било одредба што се однесува на правата на припадниците на заедниците, вклучувајќи ги особено членовите 7, 8, 9, 19, 48, 56, 69, 77, 78, 86, 104 и 109, како и одлука за додавање која било нова одредба која се однесува на предметот на тие одредби и тие членови, ке биде потребно двотретинско мнозинство гласови од вкупниот број пратеници во кое мора да има мнозинство гласови од вкупниот број пратеници кои припагаат на заедниците што не се мнозинство во Република Македонија. Имено со имплементација на овие амандмани се направија темелни измени и оттука се овозможи и имплементацијата на целиот ОРД од кои произлегоа и низа нови или изменети и дополнети закони, а паралелно на тоа се овозможи немнозинските заедници директно да влијаат во креирање на политики и одлуките поврзани со мултикултурните прашања.

Во продолжение следи кратка анализа на допринесот на имплементацијата на ОРД во напредокот на земјата во евро-атлантскиот процес.

\section{2. Имплементацијата на принципите vis-à-vis евро-атлантскиот интегративен процес}

И покрај меѓуетничките тензии и воената криза која ќе следи, во екот на самиот вооружен конфликт на 9 април 2001 година, Македонија беше првата земја од регионот која ја потпиша Спогодбата за Стабилизиација и Асоцијација. Склучувањето на оваа спогодба преставуваше прв сериозен чекор во соработката и мотив за решавање на внатрешните проблеми и отпочнување на реформниот процес. Имено откако во ноември 2000-та година на Самитот одржан во Загреб отпочнаа преговорите за Процесот за Стабилизација и Асоцијација, беше изјавено дека „сите држави учеснички во процесот се потенцијални кандидати за приклучување кон Европската Унија, ${ }^{26}$. На 5 декември истата

1 на Амандман XII се заменува членот 78 од Уставот на Република Македонија; со точката 1 на Амандман XIII се дополнува ставот 2 на членот 86 од Уставот на Република Македонија; со Амандман XIV се дополнува ставот 2 на членот 104 од Уставот на Република Македонија; Со Амандман XV се заменува ставот 2 на членот 109 од Уставот на Република Македонија; со Амандман XVI се заменува ставот 5 на членот 114 од Уставот на Република Македонија; со точката 1 на Амандман XVII се заменува ставот 1 на членот 115 од Уставот на Република Македонија; Со Амандман XVIII се додава нов став 4 на член 131 од

Уставот на Република Македонија.

25 Со амандман X се замени членот 69 од Уставот на Република Македонија и истиот во точка 2 предвидува: За закони кои директно ги засегаат културата, употребата на јазиците, образованието, личните документи и употребата на симболите, Собранието одлучува со мнозинство гласови од присутните пратеници, при што мора да има мнозинство гласови од присутните пратеници кои припаѓаат на заедниците кои не се мнозинство во Република Македонија.

${ }^{26}$ Врз основа на Лисабонската директива донесена за време на Европскиот Совет од март 2000-та година, на следниот Совет, во Санта Мариа де Фиера (19-20 giugno 2000) беше потврдено дека 
година Советот на Европа го усвои Правилникот бр. 2666/2000 за активирање на програмите КАРДС ${ }^{27}$ чија првична цел беше да се подржи зајакнувањето на демократиите и економската и институционална стабилност на земјите, преку подршка на владините органи на национално и локално ниво и на институциите од граѓанското општество. Помошта подразбираше создавање на институционална и законодавна рамка за поткрепа на демократијата, правната држава, човекови и малцински права и истите беа услов за користење на истата $^{28}$. По неколкудошните спроведени реформи врз основа на европските препораки, во февруари 2004 година, Европскиот совет ја зема во предвид ратификацијата на Спогодбата направена од страна на земјите членки на ЕУ, а еден месец подоцна македонскиот парламент ја усвои Декларацијата за прием на барањето за интеграција кон Европската Унија (доделена на 22 март 2004 во Даблин). Како што беше предвидено во процесот, Европскиот совет побара од Комисијата да подготви Мислење во однос на ова барање. На 1 Октомври истата година, Престседателот на европската Комисија Романо Проди и го додели на Македонија прашалникот, преку кој се направи скенирање на капацитетите на земјата согласно европските стандарди односно критериумите од Копенхаген. Во помалку од 3 месеци македонските институции ги имаа подготвено одговорите, претставувајќки ја ситуацијата и постигнатиот успех во секој сектор од општеството. На почетокот на 2005 година (15.02.2005) европскиот прашалник беше комплетиран и доставен до Претстседателот на европската комисија Бароссо. Истата година Комисијата го публикуваше нејзиното мислење во однос на поднесеното барањето и во месец декември Македонија доби позитивен одговор со кој се здоби со статус потенцијален кандидат за прикулучување кон ЕУ ${ }^{29}$. Во Преамбулата на Комуникација се одредува дека Република Македонија е дел од еден историски процес во кој се вклучени сите земји од Западен Блакан, кои ја надминуваат политичката криза во регионот и се подготвуваат да влезат во зоната на мирот, стаблиноста и просперитетот, формирана од Унијата ${ }^{30}$. Покрај ова позитивна оцена беше дадена и во однос на

максималната можна интеграција на земјите од регионот во економскиот и политички контекст на Европа, преку Процесот за Стабилизација и Асоцијација, останува една од основните цели.

27 Неопходните мерки за имплементација на Правилникот беа донесени во согласност со одлуките на Советот од 1999/468/Ес од 28 јуни 1999 година. До оваа дата европската подршка беше давана во рамките на Прогрмата ОБНОВА (Council regulation n.1628 од 25 јули 1996) е Програмата ФАРЕ (Council regulation n.3906 од 18 декември 1989).

${ }^{28}$ Council regulation (EC) No 2666/2000 of 5 December 2000, (17.12.2000), Official Journal of the European Communities, (05.05.2021) Retrieved from http://eur-lex.europa.eu/LexUriServ/LexUriServ.do?uri=OJ:L:2000:306:0001:0006:IT:PDF

29 Имено во комуникацијата со европкската комисија од 9 ноември 2005 година во однос на барањето на приклучувањето на Македонија кон ЕУ, беше формулирано мислењето во контекст на правната рамка согласно членот 49 од Договорот за Европска Унија.

${ }^{30}$ Comunicazione della Commissione, Il Parere della Commissione sulla domanda di adesione dell'ex Repubblica iugoslava di Macedonia all'Unione europea (9.11.2005), Commissione delle Comunità 
волјата за имплементирање на ОРД и постигнатите резултати од 2001 до тогаш, кои се сметаа за есенцијални за стабилноста на земјата. Во овој контекст беше нагласено дека со активирање на законската програма предвидена од ОРД, ќе се допринесе до подобрување на политичката и безбедносната состојбата на земјата. За да се задржи климата на доверба и да се консолидираат добинеите разултати, Комисијата препорача дека владата треба да продолжи со ефектвна имплементација на договорот ${ }^{31}$ и дополнително активирање на реформи во полицијата, во правниот систем и во борбата за корупција.

Како овие програми беа усогласени со она што го предвидуваа принщипите на ОРД?

Целосно и безусловно отфрлање на употреба на насилство за остварување на политички иели беше првиот приницип од ОРД кој претставува основа и за останатите. За да се прекинат непријателствата најпрвин како што беше споменато се изврши разоружување, а потоа се продолжи со интегративните чекори кои беа веќе отпочнати. Овој принцип е тесно поврзан со атлантската интеграција на Македонија ${ }^{32}$, која пак се темели на Одлуката за стапување во НАТО, донесена во 1993 година, потоа Партнерството за мир од 1995 година и статусот кандидат за членство кој Македонија го доби во 1999 година. После конфликтот во 2001 година, следната година македонската армија почна да учествува во мисиите на Алијансата во Авганистан, во 2003 ја потпиша Повелбата за партнерство (Јадранска повелба), во 2005 година беше вклучена во Концептот за оперативни способности на НАТО, а во 2008 година иако беа исполнети условите за членство и беше потврден напредокот, зарди грчкото вето Македонија, не успеа да стане членка. Во годините кои ќе следат се продолжи со допринес во НАТО мисиите, преку мисијата Одлучна поддрика, која отпочна во 2015 година, а само после потпишувањето на Преспанскиот договор ${ }^{33}$ на 27 март 2020 година Македонија конечно стана 30-тата полноправна членка на Северноатлантската Алијанса. Навраќајќи се на првиот принцип на ОРД за чие остварување беше вклучен и НАТО, почитувањето на овој принцип и неговото имплементирање секако дека придонесе во тоа да се продолжи онаму каде што конфликтот направи застој, односно да обезбеди стабилност ${ }^{34}$, која претставува

Europee, Bruxelles, COM (2005) 562 definitivo SEC(2005) 1425, SEC(2005) 1429 (15.05.2021) Retrieved from http://eur-lex.europa.eu/LexUriServ/LexUriServ.do?uri=COM:2005:0562:FIN:IT:PDF ${ }^{31}$ Ибид

32 30. Број за паметење. Северна Македонија полноправна членка на НАТО!, (26.03.2020), Министерство за одбрана на РМ, (10.05.2021) Retrieved from https://mod.gov.mk/republika-severnamakedonija-30-zemja-clenka-na-nato/

33 Преспанскиот договор беше потпишан во јуни 2018, а влезе во сила во февруари 2019 година. Протоколот за пристапување во НАТО се потпиша на 6 февруари 2019 година, а следната година на 20 март 2020 година после комплетирање на ратификацијата од страна на сите членки на НАТО беше потпишан Инструментот за пристапување на Северна Македонија во НАТО.

34 Според аналитичарот Шалти настаните од 2001 година во Македонија предизвикаа загриженост заради можната ескалација на борбите и појава на голем број бегалци, што сериозно 
услов не само за интеграцијата во НАТО, туку и за оставрување и развој во секое општество. Имено токму ова беше нагласено и во самиот ОРД, односно дека „само мирни политички решенија можат да ја загарантираат стабилната и демократска иднина на Македонија,.

Вториот принцип, кој се однесува на зачувување на суверениот $u$ територијалниот интегритет на Македонија, како и на унитарниот карактер на државата, изрично наведува дека за етничките прашања не постојат територијални решенија. Од овој принцип се подразбира дека државата мора да остане унитарна, за да продолжи на својот пат во евро-атлантскиот процес. Иако во принципот се наведува дека не постојат територијални решенија, сепак од договорот произлегоа законски измени кои на некој начин беа поврзани со територијални решенија, но во рамките на унитарноста на државата. Контраверзно во овој процес беше што во прекројување на општинските граници етнчикиот состав на општините имаше предност во однос на економскиот критериум. Меѓутоа ваквото решение изгледа беше најдобриот начин да се стабилизира државата и да се зачува територијалниот интегритет и нејзината унитарност, а со тоа и да се пружи стабилна основа за интегративниот процес на Македонија во ЕУ и НАТО. Имено стабилизацијата беше предвидена во сите КАРДС програми како темел во евроинтегративниот процес. Нивната имплементација за подршка на земјата отпочна во 2001 година и врз основа на прогресот кој го правеше државата, Европската комисија еднаш годишно го даваше своето мислење. Според мислењето на Комисијата изразено во Извештајот за стабилизација и асоцијација за Македонија ${ }^{35}$, политичката ситуација во 2004 година беше оценета како стабилна, а еден од главните предизвици на владата беше да гарантира имплементација и ефективна реализација на процесот на децентрализација. Овој процес беше неопходен и клучен и за остварување на петтиот принцип развој на локалната самоуправа, за кој во Извештајот се вели дека треба да овозможи приближување на владата до народот и подобрување на достава на јавните услуги, а дека успехот зависи од рационализирање на големината и бројот на општините (во кои ќе се зголемат фискалните и управувачки капицитети) и од пренесување на надлежностите набројани во чл.22 од Законот за локална самоуправа на општинско ниво. Следната година, во 2005, беше потпишан Акцискиот план за Европско Партнерство ${ }^{36}$, во кој се наведуваше дека е потребно да се заокружи

би го дестабилизирал регионот и би ги загрозил интересите на САД во европската безбедност. Велјановски, С., (2007), Геополитиката на САД во конфликтите на Балканот (1990-2001), Балкански форум за безбедност, Скопје, (стр.157)

${ }^{35}$ Commissions working paper former Yugoslav Republic of Macedonia, Stabilization and Association Report 2004, (2004), Commission of European Communities, Bruxelles, xxx SEC (2004) 373, COM (2004) 204 final. (15.05.2021) Retrieved from https://wbc-inco.net/object/document/7128.html

${ }^{36}$ Акииски план за европско партнерство 2005, (јануари 2006), Собрание на Северна Република Македонија, (15.05.2021) Retrieved from https://www.sobranie.mk/WBStorage/Files/Akciski plan 
законската рамка за спроведување на процесот на децентрализација и да се обезбеди општините да имаат потребни средства за спроведување на новите надлежности. Од 2006 година па натаму Мисијата на ОБСЕ од Скопје почна да изготвува проценки за развојот на процесот на децентрализација, со препораки и предлози за локалната и централната власт. Од кога во 2012 година увиде дека процесот е влезен во втората фаза, Мисијата се фокусираше на одредени области кои се во согласност со тригодишната Програма за имплелемтација на процесот ${ }^{37}$. Во 2015 година пак, Владата донесе Програма за одржлив локален развој и децентрализација во РМ за периодот 2015-2020, а истата во 2018 беше ревидирана согласно актуелните политики, приоритети и трендови на одржлив развој и децентрализација во земјата, на европско и на глобално ниво 38 .

Зошто децентрализацијата и локалната самоуправа играат толку голема улога за развој на државата и нејзиниот од кон ЕУ? Децентрализацијата и развојот на локалната самоуправа беа оценети како клучните приоритети, затоа што иако Законот за локална самоуправа од 1995 година беше донесен, тој наместо да води кон развој, ја врати земјата наназад. Заради таа причина во 1997 година земјата ја ратификуваше Повелбата за локална самоуправа, во 1999 усвои Стратегија за реформи во локалната самоуправа, а со измената на уставот од 2001 година се отвори пат за нејзино остварување. Имено како што беше горе наведено целта беше, владата да се приближи кон народот и истиот да може да биде поблиску вклучен во развојот на земјата. Овој инструмент беше избран како клучен за задржување на територијалниот интегритет и унитарноста на земјата, која е и основен услов, заедно со мирот и стабилноста од претходната точка, за интеграцијата во ЕУ. Меѓутоа нагативниот резултат кој произлезе од измените кои беа направени во рамките на процесот на децентрализацијата е што примената на етничкиот критериум при криерање на новите општински граници доведе до сегрегација и немање меѓуетничка кохезија.

Во однос на третиот принцип одразување на мултиетничкиот карактер во јавниот живот, иако Спогодба за Стабилизација и Асоцијација не содржеше ниту една клаузола која се однесува директно на заштитата на малцинствата (освен онаа дека нивната гаранција треба да биде во согласност со европските и меѓународни норми) во програмите КАРДС беше воведена асистенција за спорведувањето на одредбите на Охридскиот Рамковен Договор, додека со Акцискиот план за европско партнерство од 2005 година, се одредуваше дека треба да се обезбеди ефикасно спроведување на законската рамка усвоена za_Evropsko_partnerstvo_2005(1)\%2008.02.06.PDF

${ }^{7}$ Аналитички извештај за процесот на децентрализација, (септември 2014), Мисија на ОБСЕ во Скопje, (15.05.2021) Retrieved from https://www.osce.org/mk/skopje/231586

38 Програма за одржлив развој и децентрализачија во Република Македонија 2015-2020 (ревидирана), (2015) Министерство за локална самоуправа на PM, (15.05.2021) Retrieved from http://mls.gov.mk/images/documents/regionalenrazvoj $/ 2 . \% 20 \% 20 \% 20 \% 20$ Programa $\% 20 \mathrm{za} \% 20$ odrzliv\%20lokalen $\% 20$ razvoj\%20i\%20\%20decentralizacija-Revidirana-Precisten $\% 20$ tekst-MAKlektor.pd 
во согласност со Рамковниот договор, во кој влегуваа и мерките за градење меѓуетничка доверба. Одредби кои беа поврзани со овој принцип се однесуваа на употреба на јазикот на немнозинските заедници, изразување на идентитетот, употреба на симболи и имплементирање на одредбата за недискриминација и правичната застапеност, со крајна цел: мирно, стабилно и демократско општество. Употребата на јазикот и знамињата на немнозинските заедници почна да се имплементира, но не целосно и не секогаш во рамките на законот. Ова последното се однесува пред се на злоупотреба на знамињата, односно нивна непрописна употреба и не употреба на службениот јазик на државата во одередени сегменти од јавната сфера ${ }^{39}$.

Тргнувајќи од тоа дека Европската Унија е збир на различни нации кои заедно ја градат иднината на Унијата, секоја потенцијална членка треба, пред се да овозможи слога и взаемна партиципација во своите национални граници, за да може да ги прифати и различностите во рамките на Унијата. Затоа како во критериумите, така и во сите други документи, едно од начелата на кое се обрнува посебно внимание се правата на малцинствата во земјите членки, нивното почитување и заштита. Меѓутоа не треба да се изостави дека иако заштитата на малцинствата е еден од основните критериуми за приближување кон „европската реалност,, истиот не беше на еднаков начин мониториран кај другите членки од Централна и Источа Европа, највероватно од причина што во Македонија барањата за повеќе права беа причина за вооружениот конфликт, а кај другите не. Имено, Македонија иако во 1991 година доби позитивна оцена од Арбитражната Комисија, (во рамките на Декларацијата на европската заедница за Југославија ${ }^{40}$, во чиј извештај покрај другото се оценуваше и заштита на малцинствата), во 2001 година го смени својот устав и низа закони со цел да одговори на потребата на мултикултуралната реалност.

Во однос на одредбата за правична застапеност, покрај тоа што беше предвидена за да се намали невработеноста, истата требаше да го регулира и балансот по етничка линија во јавната и државната администрација. Во резултатите од Посебниот извештај на Народниот правобранител од 2019 година ${ }^{41}$ се заклучува дека институциите немаат желба и капацитет да се справат и да го имплементираат во целост начелото на соодветна и правична застапеност, бидејќи целото истражување кое се спроведува од страна на Народниот правобранител во текот на последователни 12 години, укажува на

\footnotetext{
${ }^{39}$ Галева, Ј., Уставните права на немнозинските заедници во Република Македонија и нивната примена во пракса, во Зборник на трудови-Охридска школа на правото, Институт за правноекономски истражувања и едукација Јурдика Прима, Скопје, (стр.238-9)

${ }^{40}$ Conference on Yugoslavia Arbitration Commission, Opinion on question arising from the dissolution of Yugoslavia, (18.06.2021) Retrieved from https://www.pf.uni-li.si/media/skrk mnenja.badinterjeve. arbitrazne.komisije.1 .10.pdf

${ }^{41}$ Извештај за следењето на примената на начелото на соодветна и правична застапеност за 2018 година, (2019), РСМ, Народен Правобранител, Скопје, http://ombudsman.mk/upload/ documents/SPZ/SPZ-2018-Mk.pdf www.ombudsman.mk
} 
благ квантитативен раст, односно привиден напредок во примената на начелото на соодветна и правична застапеност, но не и квалитативен напредок, со што би се воспоставило општество во кое сите подеднакво би ги уживале уставните и законски загарантирани права. Споредбено со претходната година се посочува на селективната состојба која владее во јавниот сектор, пред сѐ поради констатацијата дека кај институциите каде раководниот кадар го сочинуваат припадници на македонската и албанската етничка заедница, застапеноста на припадниците на помалите етнички заедници воопшто не е видлива или е на многу ниско ниво, односно каде што раководителот е Македонец, раководните и нераководните лица вработени во институцијата претежно се припадници на македонската заедница, што соодветствува на состојбата доколку раководителот е припадник на албанската етничка заедница.

Во однос на мерит систем на вработување, кој се промовира и со Охридскиот рамковен договор и во законската регулатива, може да се каже дека воглавно истиот фигурира само на хартија, затоа што во пракса дадена е предност на принципот за соодветна и правична застапеност. Отука се поставува прашањето: како начелото за правична застапеност ке не доведе едно скалило понапред во интегративниот процес, ако се вработува по етничка линија, (само со цуел да се постигне баланс и квантитет), а не согласно мерит принципот кој би довел до квлаитет? Од извештајот за проценка на напредокот на Република Македонија во исполнување на политичките критериуми неопходни за членство во ЕУ ${ }^{42}$ (Извештај на ЕУ), како слабости во македонскиот административен систем се заблежани следните: партијата е детектирана како работодавец; непотизмот сеуште игра улога во вработувањата; не постои систем на мерење на учинокот на вработените административни службеници и за сите вработени во јавниот сектор; постојат заобиколени механизми за вработувања, кои ги уништуваа филтрите напишани на хартија со првиот закон за државни службеници од 2000. Според препораките од Извештајот на ЕУ, системот за правична застапеност потребно е да се потпира или комбинира со мерит системот, кој предвидува вработување и напредување според заслуги.

Другото прашање кое се поставува во овој конктекст е како овој принции ќе допринесе до изразување на мултикултурализмот во јавната сфера? Во овој контекст е секогаш корисно да се земе во предвид теоријата на британскиот социолог Џон Рекс, според кој „во јавната сфера, државата треба да гарантира еднакви можности за сите индивидуи, како и гаранција на еднкавост без никаква дискриминација на сите граѓани пред законот, заради која причина истата нема обврска да прави разлика врз основа на етничко потекло, односо примена на

\footnotetext{
${ }^{42}$ Блажевски, Т., Ризаов, Г., (2019), Извештај за проиенка на напредокот на Република Македонија во исполнување на политичките критериуми неопходни за членство во ЕУ, Петти дел: Мерит системот и дигитализаиија на услугите - формула за оптимална и квалитетна администрација, Фондација Метаморфозис, Скопје, (02.04.2020) Retrieved from https://www.metamorphosis.org.mk/
} 
позитивна дискриминација. Ваквиот начин на одвојување на јавната сфера (во која сите индивидуи треба да имаат еднаков третман) и приватната сфера (во која е дозволено е признавање на етничките, религиозните, јазичните и други разлики) всушност се промовира моделот на демократскиот (егалитарен) мултикултурализам ${ }^{43}$. Во македонскиот случај иако се користи терминот застапеност на сите заедници, кој алудира на еднаков тертман, спротивно на него во пракса се спроведува фаворизирање на помалку застапените заедници, (пред се на поголемата немнозинска заедница) и се применува вработување по етничка линија.

Во однос на четвртиот принцип, кој се однесува на исполнување на потребите на граѓаните преку уставот, согласно развојот и созревањето на демократската држава се чини дека е принцип кој остава отворена врата за измени на уставот во било кое време. Може да се каже дека овој принцип целосно се исполнува почнувајќи со имплементација на амандманите во 2001 година до последните усвоени во 2019 година. Измените од 2001 година беа тесно поврзани со условот за употреба на бадинтеровото правило, а преку нивна имплементација се овозможи и реализација на ОРД, од кои пак произлегоа и низа нови или изменети и дополнети закони. Дека уставот е флексибилен односно се прилагодува на потребите на граѓаните согласно развојот на државата зборуваат и последните измени направени со амандманот 34 од 2019 година со кој се направи измена во Преамбулата-Амандман 4 на Уставот ${ }^{44}$. Согласно овие измени, во Преамбулата како елементи врз кои се конституира државата, се воведоа Прогласот од Првото заседание на АСНОМ и Охридскиот рамковен договор, а се тргна „и како и граѓаните кои живеа во нејзините граници кои се,, со цел можеби појако да се нагласи еднаквоста помеѓу сите граѓани во РМ и инвната припадност кон државата ${ }^{45}$. Делот од преамбулата во кои се направени измените гласи: Граѓаните на Република Македонија, Македонскиот народ, дел од албанскиот народ, турскиот народ, влашкиот народ, српскиот народ, ромскиот народ, бошњачкиот народ и другите, преземајќи ја одговорноста за сегашноста и иднината на нивната татковина, свесни и благодарни на

\footnotetext{
${ }_{43}$ Colombo, E., (2002), Le società multiculturali, Carocci, Roma, (p.89)

${ }^{44}$ Во Преамбулата се избришаа зборовите: „како и граѓаните кои живеат во нејзините граници кои се,,; потоа „одлуките на АСНОМ,, се заменија со „правните одлуки кои се наведени во Прогласот од Првото заседание на АCHOM до македонскиот народ за одржаното заседание на АCHOM, а по зборот „година,, се додаваат зборовите: “на кои се изрази волјата за создавање на самостојна суверена држава и Охридскиот рамковен договор“ а се бришат зборовите „одлучија да,..

${ }^{45}$ Имено, одма после „македонски народ,, се набрјува другите делови од народи, за кои не се специфицира веќе дека живеат во рамките на нејзините граници. Реченицата од амандамнот 4 фактички два пати го споменуваше терминот граѓани, пред терминот македонски народ и повторно после македонски народ однесуваќи се на оние кои живеат во рамките на нејзините граници, а се дел од други народи. Ваквата поставеност можеби беше направена за да се направи разлика од другите народи или делови од овие народи кои живеат во нивните матични или други земји или пак да се нагласи конститутивноста на македонскиот народ.
} 
свочте предчи за жртвите и посветеноста во нивните заложби и борба за создавање самостојна и суверена држава Македонија и одговорни пред идните генерации за зачувување и развој на се ито е вредно од богатото културно наследство и соживот во Македонија, еднакви во свочте права и обврски кон заедничкото добро - Република Македонија - во согласност со традицијата на Крушевската Република и правните одлуки кои се наведени во Прогласот од Првото заседание на АСНОМ до македонскиот народ за одржаното заседание на АСНОМ и на Референдумот од 8 септември 1991 година, на кои се изрази волјата за создавање на самостојна суверена држава и Охридскиот рамковен договор, ја конституираат Република Македонија како самостојна, суверена држава.

\section{Заклучок}

Тргнувајќи од општата одредба која е содржана во членот 2 од Договорот за Европската Унија, во кој се одредува дека Унијата се основа врз вредностите на почитување на човечкото достоинство, слободата, демократијата, еднаквоста, правната држава и почитување на човековите права, вклучувајќи ги и правата на припадниците на малцинствата, се подразбира дека секој нов член кон унијата треба најпрвин да ги почитува овие вредности во сопствената држава, за да ги почитува и заедничките на унијата. Во Македонија покрај бројните политики кои се спроведуваат со цел да се достигнат овие европски стандарди, Охридскиот Рамковен Договор беше креиран како рамка од кој произлегоа битни измени кои беа клучни не само во процесот на евро-атлантската интеграција, туку и за развојот на демократското општество. Од гореизнесената кратка анализа би можело да се заклучи дека остварувањето на првиот и вториот принцип од Охридскиот Рамковен Договор (отфрлағе на употреба на насилство за остварување на политички иели и зачувување на суверенитетот и територијалниот интегритет на Македонија и нејзиниот унитарен карактер) беа основа за да мирно и стабилно се продолжи на патот кон ЕУ; третиот и петиот принцип (одразување на мултиетничкиот карактер во јавниот живот и развој на локалната самоуправа) претставуваат услов за поголема и поеднаква партиципација на сите граѓани во општествениот и политичкиот живот што доведува до функционално и поразвиено општество; додека четвртиот принцип (исполнување на потребите на граѓаните преку уставот согласно развојот и созревањето на демократската држава) е оној кој овозможува прилагодување на потребите на граѓаните и претставува отворена врата или клучот кон демократското општество и сето она што истото го нуди и бара. Аномалиите кои пак кои ги донесе ОРД се: внатрешна етничка сегрегација, наместо кохезија и интеграција; превработеност во државната администрација и занемерување на мерит систем кои резултураат со неефикасност и нефункционалност; постојано користење на ОРД за нови барања и измени, наместо усвојување на стабилни 
и одржливи политики; непостоење на меѓуетничка унитарност и припадност кон државата, која може да се воочи и од употреба на симболи на етничките заедници кои ги врзува со народи од други држави, а не со заедничката историја на граѓаните на македонската држава. Денес, во годината кога се слави 30 години од независноста на државата, 20 години од потпишувањето на ОРД, 16 години од добивањето на статус кандидат за пристап кон ЕУ, 3 години од промената на името на државата во Северна Република Македонија, државата е дел од НАТО алијансата, но не и од ЕУ. И покрај сите напори за нејзин развој согласно демократските принципи и критериумите на европските политики, државата може да се каже дека повеќе беше закочена од спорот со Грција за името и моменталниот спор со Бугарија, кои немаат никаква врска со направениот прогрес во рамките на ОРД и се косат со прниципите на ЕУ. ОРД секако допринесе во прогресот на Македонија согласно евро-атланстските политики, иако како што беше напоменато доведе и до одредени внатрешни нефункционаности.

\section{Библиографија}

1. 30. Број за паметење. Северна Македонија полноправна членка на НАТО!, (26.03.2020), Министерство за одбрана на РМ

2. Акииски план за европско партнерство 2005, (јануари 2006), Собрание на Северна Република Македонија

3. Аналитички извештај за процесот на децентрализација, (септември 2014), Мисија на ОБСЕ во Скопје

4. Арифи, Б., (09.05.2018), Диво Насеље: Македонска шпионска мистерија, Призма.мк, Скопје,

5. Блажевски, Т., Ризаов, Г., (2019), Извештај за проценка на напредокот на Република Македонија во исполнување на политичките критериуми неопходни за иленство во ЕУ, Петти дел: Мерит системот и дигитализаиија на услугите - формула за оптимална и квалитетна администрација, Фондација Метаморфозис, Скопје

6. Близнаковски, Ј.,(Април 2014), Локалнијазичниполитикизанемнозинските заедници, можности за поефективна имплементација, Институт за демократија Социетас Цивилис-Скопје, Институт за развој на заедницата

7. Colombo, E., (2002), Le società multiculturali, Carocci, Roma

8. Commissions working paper former Yugoslav Republic of Macedonia, Stabilization and Association Report 2004, (2004), Commission of European Communities, Bruxelles, xxx SEC (2004) 373, COM (2004) 204 final

9. Comunicazione della Commissione, Il Parere della Commissione sulla domanda di adesione dell'ex Repubblica ingoslava di Macedonia all'Unione europea (9.11.2005), Commissione delle Comunità Europee, Bruxelles, COM (2005) 562 definitivo SEC(2005) 1425, SEC(2005) 1429 
10. Conference on Yugoslavia Arbitration Commission, Opinion on question arising from the dissolution of Yugoslavia

11. Council regulation (EC) No 2666/2000 of 5 December 2000, (17.12.2000), Official Journal of the European Communities

12. Галева, J., (2016), Влијанието на Охрдискиот рамковен договор врз правната регултива и пракса за вработување, 349.2:340.13]:321.7(497.7) „2001“, Списание на научни трудови „Меѓународен дијалог Исток-Запад,, Vol.3, N.2, Меѓународен центар за славјанска просвета- Свети Николе, Свети Николе

13. Галева, J. (2019), Уставните права на немнозинските заедници во Република Македонија и нивната примена во пракса, во Зборник на трудовиОхридска школа на правото, Институт за правно-економски истражувања и едукација Јурдика Прима, Скопје

14. Извештај заследенето на применатананачелото на соодветнаи правична застапеност за 2018 година, (2019), РСМ, Народен Правобранител, Скопје

15. Кољо: Политичарите не изманипулираа со „,тиранската платформа, (21.02.2019), Tocka.com.mk https://tocka.com.mk/vesti/298779/koljopoliticarite-n-izmanipuliraa-so-tiranskata-platforma

16. Laity, M., (2009), Preventing war in Macedonia, Pre - Emptive Diplomacy for the 21 st Century, RUSI Кралски институт на заедничките служби, (стр.84); (превод: Марк Лејти, Спречување војна во Македонија Превентивна дипломатија за 21 век, Вајтхол труд, Фндација Институт отворено Општество-Македонија, 2009)

17. Ландов, К., Русковска за 27 април: Се се знаело, било испланирано, не се знаел датумот- тоа го докажавме (01.07.2021), Alon.mk

18. Маролов, Д., Стојановски, С., (2017) Охридскиот рамковен договор наспроти Тирана платформа, Зборник на трудови „Општествените промени во глобалниот свет,,, Универзитет Гоце Делчев, Штип

19. Марушиќ, J., С., (22.02.2021) Случајот Монструм пред својата завршница, Balkan Transitional justice

20. Програма за одржлив развој и децентрализација во Република Македонија 2015-2020 (ревидирана), (2015) Министерство за локална самоуправа на PM

21. Sokhey W. S., Gjukovikj, D, (29.05.2017), This is why the West should pay attention to the drama in Macedonia, Washington Post

22. Stabilization and Association Agreement, (26.03.2001), Council of The European Union, Brussels

23. Стојначов, С., (26.06.2020), Агенција за разузнавање има нови сознанија за „Диво насеље,, Радио Слободна Европа,

24. Спогодба, Конечна Спогодба за ремавање на разликите опишани во резолуциите 817 (1993) и 845 (1993) на Советото за безбедност на 
Обеддинетите Начии, за престанување на важноста на привремената спогодба од 1995 г. и за воспоставување на стратешко партнерство меѓ у страните (12.06.2018), Влада на РМ

25. Велјановски, С., (2007), Геополитиката на САД во конфликтите на Балканот (1990-2001), Балкански форум за безбедност, Скопје.

26. Указ за прогласување на Закон за употреба на јазииите, (14.03.2018), Агенција за примена на јазикот

27. Закон за употреба на јазиците кои го зборуваат најмалку $20 \%$ од граѓаните во РМ и во единиците на локалната самоуправа, (13 август 2008), Службен Весник, бр. 101 год. LXIV, Скопје;

28. Закон за заштита и унапредување а правата на припадниците на заедниците кои се помалку од 20\% во РМ, (22 јули 2008), Службен Весник бр. 92 год. LXIV, Cкопје

29. Закон за употреба на знамињата на заедницте во РМ, (19.07.2005), Службен весник на РМ, бр.58/05

30. Закон за изменување и дополнување на закон за употреба на знамињата на заедницте во РМ, (25.07.2011), Службен весник на РМ бр.100 од 2011

31. Закон за изменување на Законот за празниците на Република Македонија, (15.02.2007), Службен весник на РМ бр. 18 од 2007

32. https://mod.gov.mk/republika-severna-makedonija-30-zemja-clenka-na-nato/

33. https://www.sobranie.mk/WBStorage/Files/Akciski_plan_za_Evropsko partnerstvo 2005(1)\%2008.02.06.PDF

34. https://www.osce.org/mk/skopje/231586

35. https://prizma.mk/divo-nasele-makedonska-shpionska-misterija/

36. https://www.metamorphosis.org.mk/

37. https://idscs.org.mk/wp-content/uploads/2009/08/ljp-nemnozinski-zaednicimkd.pdf

38. https://wbc-inco.net/object/document/7128.html

39. http://eur-1ex.europa.eu/LexUriServ/LexUriServ. do?uri=COM:2005:0562:FIN:IT:PDF

40. https://www.pf.uni-lj.si/media/skrk mnenja.badinterjeve.arbitrazne. komisije.1_.10.pdf

41. http://eur-lex.europa.eu/LexUriServ/LexUriServ.do?uri=OJ:L:2000:306:0001: 0006:IT:PDF

42. http://ombudsman.mk/upload/documents/SPZ/SPZ-2018-Mk.pdf

43. https://www.fosm.mk/CMS/Files/Documents/Sprecuvanje-vojna-vnatresnimark-lejti.pdf

44. https://a1 on.mk/macedonia/ruskovska-za-27-april-se-se-znaelo-biloisplanirano-ne-se-znael-datumot-toa-go-dokazhavme/ 
45. https://www.washingtonpost.com/news/monkey-cage/wp/2017/05/29/this-iswhy-the-west-should-pay-attention-to-the-drama-in-macedonia

46. http://mls.gov.mk/images/documents/regionalenrazvoj/2.\%20\%20\%20 \%20Programa\%20za\%20odrzliv\%20lokalen\%20razvoj\%20i\%20\%20 decentralizacija-Revidirana-Precisten\%20tekst-MAK-lektor.pd

47. https://www.washingtonpost.com/news/monkey-cage/wp/2017/05/29/this-iswhy-the-west-should-pay-attention-to-the-drama-in-macedonia

48. http://ec.europa.eu/enlargement/pdf/the former yugoslav republic of macedonia/saa03 01 en.pdf

49. https://www.slobodnaevropa.mk/

50. https://vlada.mk/node/17422

51. https://apj.gov.mk/wp-content/uploads/2019/06/Zakon-za-upotrebajazitsite-14-01-2019.pdf 